\title{
Students' Perspectives toward Virtual Classes Effectiveness on EFL Learners' Communication Skills at Prince Sattam Bin Abdulaziz University
}

Luluh Abdullah Alkathiri

English Department, College of Sciences and Humanities, Hotat Bani Tamim, Prince Sattam Bin Abdulaziz University, Al-Kharj, Riyadh, Kingdom of Saudi Arabia

Corresponding Author: 1.alkathiri@psau.edu.sa

Alanoud Abdulaziz Alkulaib

English Department, College of Sciences and Humanities, Hotat Bani Tamim, Prince Sattam Bin Abdulaziz University, Al-Kharj, Riyadh, Kingdom of Saudi Arabia

\section{Bashaer Saleh Batays}

English Department, College of Sciences and Humanities, Hotat Bani Tamim, Prince Sattam Bin Abdulaziz University, Al-Kharj, Riyadh, Kingdom of Saudi Arabia

\section{Khulud Mohammed Awdah}

English Department, College of Sciences and Humanities, Hotat Bani Tamim, Prince Sattam Bin Abdulaziz University, Al-Kharj, Riyadh, Kingdom of Saudi Arabia

\section{Norah Rashed Bin Muwayni}

English Department, College of Sciences and Humanities, Hotat Bani Tamim, Prince Sattam Bin Abdulaziz University, Al-Kharj, Riyadh, Kingdom of Saudi Arabia

Received: $3 / 5 / 2021$

Accepted: 7/10/2021

Published: 7/262021

\section{Abstract}

The study explores students' perspectives towards virtual classes and the impact of such classes on EFL learners' communication skills. Such study is valuable due to the lack of research works that investigate EFL students' attitudes towards the effectiveness of such classes. Also, the findings can substantially improve the Saudi virtual education. Regarding the questions of the study, it answers two main questions: What are EFL learners' attitudes towards virtual classes? What is the impact of virtual classes on EFL learners' communication skills from students' perspectives? To achieve the objectives of this study, a questionnaire was administered to $50 \mathrm{EFL}$ students of levels seven and eight in English Department at the College of Sciences and Humanities at Prince Sattam Bin Abdulaziz University. The findings indicated that students had positive attitudes toward virtual classrooms. Such classes could enhance their communication, and improve their technical and self-learning skills. Based on these results, some recommendations were suggested that could be taken into consideration in future studies. First, further studies should be done to investigate the impact of virtual classes on other science classes such as Chemistry and Medicine in the COVID- 19 period. Second, such study should be conducted with a different sample of students (male). Finally, the same research can be applied to faculty members to explore their attitudes toward virtual education and its effect on communication skills.

Keywords: Attitudes, communication skills, english as a foreign language, learners, perspectives, prince sattam bin abdulaziz university, technical skills, virtual classes

Cite as: Alkathiri, L. A., Alkulaib, A.A., Batays, B. S., Awdah, K.M., \& Muwayni, N. R.(2021). Students'

Perspectives toward Virtual Classes Effectiveness on EFL Learners' Communication Skills at Prince Sattam Bin Abdulaziz University. Arab World English Journal (AWEJ) Special Issue on CALL (7). 165-177.

DOI: https://dx.doi.org/10.24093/awej/call7.12 
Arab World English Journal (AWEJ) Special Issue on CALL Number 7. July 2021

Students' Perspectives toward Virtual Classes

Alkathiri, Alkulaib, Batays, Awdah\& Muwayni

\section{Introduction}

All living creatures need communication, and it is essential, especially between humans. Communication is a basic skill among members of society, from one person to another, also between a teacher and students. Communication is one of the most overworked terms in the English Language (Dance, 1970, as cited in Lyon, 2020). Lyon (2020) says that communication is the process that conveys oral and written messages with meaning. In the past, communication was via paper letters, and then it evolved and became through multiple media. Now it has evolved to what is called distance communication ("distance education") through virtual classes. Communication is associated with technology that is indispensable these days. Hauben (1995) reported The Internet is worldwide and is one of the most important means of communication. In particular, Internet use has become a significant part of the lives of the millennial generation (as cited in Taskiran et al., 2018). Thus, this generation is also called 'netizens'. The internet is one of the most important developments of this era, and it will play a major role in changing the educational method (Throw, 1998, as cited in Al-Qahtani, 2010).

Technology has developed very significantly. It has become easy to learn English as a Foreign Language (EFL) anytime without any restrictions or troubles. This type of learning is known as distance learning. It is a system carried out by an educational institution that works to deliver the educational or training material to the learner anywhere and anytime through multiple means of communication (Al-Mousa \& Al-Mubarak, 2005, as cited in Al-Qahtani, 2010). Education that is available to the student without limitations of place or time (Al-Zaidi, 2009, as cited in Al-Qahtani, 2010). Bassiouni (2007) stated distance education is considered an effective, purposeful and important means of education, and it has become of interest to all governments and institutions. The first university that used the distance education system was in the United Kingdom in 1971 (as cited in Al-Qahtani, 2010). Distance education is one of the main self-learning methods (Mazen \& Al-Breik, 2008, as cited in Al-Qahtani, 2010).

Virtual classes are the most important example of distance learning. A virtual classroom is an online learning application that allows for live interaction between the educator and the learners as they are joining in learning training (Racheva, 2018). People have different opinions when they use these methods in education. Some of them prefer it and find that it is enjoyable and provides a lot of time to go to university and attend lessons. On the other hand, some people see it as boring and unhelpful. Anon (2007) stated virtual classes allow their users to escape from the confines of financial societies (as cited in Al-Qahtani, 2010). Virtual classes are important in the process of communication between teachers and students. This research will focus on EFL Learners' attitudes toward the impact of virtual classes on their communication skills.

The growing importance of Information and Instructional Technologies (ICTs) and their influence on teaching and learning have brought about significant changes in the academic environment in Saudi Arabia (Al-Asmari \& Rabb Khan, 2014). With the necessary technical skills to cope with the new challenges \& with a progressive vision to "empower people through creative e-learning in lifelong education"( Al-Asmari \& Rabb Khan, 2014, p. 2), Kingdom of Saudi Arabia, as many countries around the world, engaged e-earning (virtual classes) as significant means to limit the spread of Coronavirus (COVID-19) pandemic. Virtual classes include The Blackboard software that facilitates the e-learning system for learners and educators (Al-Tale, 2014, as cited 
in Al-Qahtani, 2019). Such classes include a variety of learning and educational facilities, such as chatting, whiteboard, separate rooms, sharing applications, simultaneous web browsing and commenting (Cakiroglu, 2014, as cited in Al-Qahtani, 2019). Many previous work researches conducted in this field have stated the advantages and disadvantages of integrating virtual education in learning \& teaching. Accordingly, the emphasis of this study is to identify students' perspectives of virtual classrooms and its impact on their communication skills.

This study aims at exploring EFL learners' attitudes towards virtual classes and investigating the impact of such classes on EFL learners' communication skills. McClemens (2013) reported education is, and has always been, a field in constant flux. Just as the world changes, so too must our classroom. The importance of virtual education lies in its ability to assist the learner in obtaining data, information, communication, and training through the Internet in the form of voice, image, as education nowadays depends on electronic means such as using a computer. It is a different education environment that contributes to the interaction between students and teachers. Virtual classrooms have been specifically in use by all sectors (Hoda, 2020). Saudi Arabia lacks the variety of studies that investigate the perceptions of EFL learners towards virtual classes. Hence, it may be worthwhile to design a study that investigates English Language students' attitudes towards virtual classes and its effect on enhancing their communication skills. Moreover, the findings will be valuable in improving the process of teaching and learning by Saudi curricula planners and designers.

This study attempts to answer the following questions: What are EFL learners' attitudes towards virtual classes? What is the impact of virtual classes on EFL learners' communication skills from students' perspectives? The objectives of the study are to explore EFL learners' attitudes towards virtual classes and investigate the impact of such classes on EFL learners' communication skills.

\section{Literature Review}

\section{Virtual Classroom Concept}

Parker and Martin (2010) defined virtual classrooms as an electronic learning environment that presents lectures and lessons effectively. Teachers or instructors can deliver lessons to students by distance learning. This gives students a chance to look at those lessons and build discussions through communicating with each other. As expressed by Preece (2001), virtual classrooms are any virtual society that learners can contact with others to do many activities in groups or individually to support their learning. All these concepts show that virtual classes have been defined by different scholars in the same manner. Cao, Griffin, and Bai (2009) clarified that in synchronous virtual classrooms, learners can communicate with each other through chats, videos, and participate in presentations. Whereas asynchronous virtual classrooms, lessons are recorded to allow a large number of students to attend the classes anytime (Hrastinski, 2008). This agrees with the perception provided by Dillenbourg in the long run (1999) that showed virtual learning may develop in the future, and this is what we are experiencing nowadays. From the concepts that Parker and Martin (2010), and Preece (2001) explained regarding the virtual classes, the authors can classify the virtual classes into two types: synchronous and asynchronous virtual classrooms. Thus, virtual classes show how technology continuously contributes to the educational process. 


\section{Communication Skills}

Communication skills are one of the most important distance learning skills. It has been defined by several researchers and scholars in different sources. Seiler and Beall (2005) reported communication as sharing meaning at the same time through effective means of communication (as cited in Iksan et al., 2012). Nordquist (2019) asserted that communication is the process of transmitting and getting information. Also, Schramm (1993) reported we communicate because we need to create a relationship and to convey an idea to another person (as cited in Wambui, 2015). The ability to effectively communicate with your manager is essential; you must know how to transmit and receive messages in all its forms, for example via mail, phone, or social media (Doyle, 2020). One of the basics of effective communication is choosing the appropriate channel for communication (Wambui, 2015). Wambui (2015) stated communication is a daily process that happens around us all the time. You must make sure of the method of sending information in order to reach the recipient in a way that is easy for him to understand. While, Kolarova (2018) believed that people feel positive, comfortable, and responsible when they communicate with each other. Means of communication are many and different; it may be verbal by spoken words, written through letters, and electronic through social media such as virtual classes (Nordquist, 2019). Kolarova (2018) said virtual classrooms make the learning experience closely resemble real live communication. Furthermore, it is important for the teachers to have good observation and communication skills in virtual classrooms and face-to-face communication. In fact, virtual classrooms are closer to real live communication. The major difference is the use of computers and the Internet. However, the most important outcome is that teachers can communicate with their students.

\section{The Advantages of Virtual Classes}

Technology, as a matter of course, has affected all aspects of education in this era. The Internet has made the process of distance education easier (Abu Hussein, 2016). This is what we are experiencing during the COVID-19 pandemic. One of the most distinctive features of distance learning is overcoming the space barrier. Students can take courses from anywhere and from different people in different locations. Distance learning also helps students and educators share educational resources; Through these features, the distance learning system offers many advantages to the curricula. First ,it enhances the delivery of educational courses, for instance, by integrating animation, sounds, and images. Second, teachers and students do not need to travel for a long time; for example, when learning different languages, you do not need to go outside the country to study them(Findley \& Findley, 1997; Laney, 1996; Gross, 1995, as cited in Chen, 2002). Danesh, Bailey, and Whisenand (2015) attributed the increasing interest in distance education to two important factors: first, the advancement of computing and communication technologies and, second, the change in the demographics of university students. The authors emphasized the role that communication plays in the success of distance education and its nature as a group activity. Effective communication is possible when the participants share a common ground such as mutual knowledge, beliefs, and assumptions in conversation. As an expansion of the interaction model proposed by Moore in 1989, Danesh et al. (2015) indicated three basic types of interaction in distance education (as cited in Al-Qahtani, 2019). Learner-content communication occurs as learners obtain intellectual information from the session. Learner-learner interaction occurs through the exchange of information, ideas, and dialogue among the students of the course. Learner-teacher interaction includes feedback and dialogue between teacher and learner. 


\section{The Disadvantages of Virtual Classes}

Distance learning environment has more strengths over traditional learning. It is effective when the curriculum is ideally presented to students. However, distance learning still has some curricular problems that need to be solved. First, some special situations are not suited to distance learning. For example, science courses like Chemistry and Biology require hands-on lab experiments. This would make a distance learning setup inadequate for such courses. Of course, instructors can communicate by a camera, but as Greenbowe and Burke (1998) noted, students who study sciences at a distance learning environment may be deprived of learning these important educational experiences and so other courses that have similar limitations to distance learning (as cited in Chen, 2002). From another point of view, Yadav (2016) discussed the advantages and disadvantages of computers and the Internet in education (as cited in Al-Qahtani, 2019). In particular, he pointed out how the use of the Internet is leading to major changes in educational models and communicational tools that easily adapt to learning styles

\section{Students' Perceptions of Virtual Classes}

Bolstad \& Lin (2009)_resented some of the experiences of students who used virtual classrooms. Some students have fun and they learn individually such classrooms (as cited in Al-Qahtani, 2019). Most researchers noted that virtual classes focus on communication between students and teachers. Whereas, some studies discussed that some students lack direct contact with their peers, indicating the possibility that online learning is not their preferred form of learning (McBrien \& Jones, 2009). Abo Alhaj (2019) said students' responses to virtual classes are vary, and teaching methods are different to facilitate the courses. Also, students can increase the opportunities to participate and interact with teachers, and as a result, students are enthusiastic about learning.

\section{Teachers' Perceptions of Virtual Classes}

Collins and Bridge (1996) stated virtual classes are important for teachers and students, as they facilitate the educational process in various ways. For example, students' interaction during the lecture and solving exercises and questions posed by the teacher on the system (Conrad, 2004, as cited in Al-Qahtani, 2019). Al-Attas (2014) mentioned that the internet has a major role in education, as it is used in research works studies and educational institutions, and the rapid development of learning processes. Most of the teachers who used virtual classrooms noted that, such classes are good in improving and facilitating learning processes (Al-Qahtani, 2019).

\section{Methods}

The method used in this study shows details about the participants, the instrument of collecting data, data analysis technique, validity and reliability of the study, the procedure in which the researchers collected the data and the research design.

\section{Participants}

The participants of this study were chosen randomly. They consisted of 50 EFL students of levels seven and eight enrolled in English Department at The College of Sciences and Humanities (Female Section) at Prince Sattam Bin Abdulaziz University in the academic year 1442 (20202021). The age average was $20-22$ years. 


\section{Research Instruments}

The researchers designed a five-point Likert scale questionnaire to collect the data of the study. Likert questions can help the authors to ascertain how strongly the respondents agree to each statement. It was divided into two categories and consisted of 16 items. The first category (1-8) was about students' attitudes towards virtual classrooms. The second category (9-16) dealt with investigating the impact of virtual classes on learners' communication skills. Also, the researchers translated the questionnaire into the Arabic Language to get accurate responses from the participants.

\section{Data Analysis Technique}

Since this study follows the quantitative approach, the researchers used SPSS and Excel to conduct the statistical analysis for the collected data.

\section{Validity and Reliability}

For validity, the questionnaire was reviewed by two Ph.D. holders to assure its validity. For reliability, Cronbach's alpha $(\alpha)$ value was calculated through Excel and is found to be 0.886 .

\section{Research Procedures}

The researchers designed and developed the questionnaire. The questionnaire was reviewed by two Ph.D. holders to assure its validity. Then, the researchers set up the questionnaire on Google Forms and sent the link to the participants. Finally, the researchers calculated Cronbach's alpha using Excel and produced the descriptive analysis and the statistical analysis of that data using SPSS.

\section{Results}

The results are divided into two sections: the first part is the results of students' attitudes towards virtual classrooms and the second part is about the results of the impact of virtual classes on learners' communication skills. The researchers statistically analyzed all data using SPSS. This can be seen in the following tables and figures:

Table 1. Students' attitudes toward virtual classrooms

\begin{tabular}{|l|c|c|c|c|c|}
\hline \multicolumn{1}{|c|}{ Statement } & $\begin{array}{l}\text { Strongly } \\
\text { Disagree }\end{array}$ & Disagree & Neutral & Agree & $\begin{array}{l}\text { Strongly } \\
\text { Agree }\end{array}$ \\
\hline 1-Virtual classes have become necessary in education. & $14 \%$ & $0 \%$ & $14 \%$ & $42 \%$ & $30 \%$ \\
\hline $\begin{array}{l}\text { 2-Virtual classes have proved that it has a higher competence } \\
\text { than the traditional classes. }\end{array}$ & $16 \%$ & $16 \%$ & $38 \%$ & $16 \%$ & $14 \%$ \\
\hline $\begin{array}{l}\text { 3-Virtual classes present the knowledge in an easy and effective } \\
\text { way. }\end{array}$ & $10 \%$ & $10 \%$ & $32 \%$ & $34 \%$ & $14 \%$ \\
\hline $\begin{array}{l}\text { 4-Virtual classrooms reduce the traditional educational loads } \\
\text { that required from students. }\end{array}$ & $8 \%$ & $18 \%$ & $14 \%$ & $36 \%$ & $24 \%$ \\
\hline $\begin{array}{l}\text { 5-Virtual classrooms develop EFL learners' technological } \\
\text { skills. }\end{array}$ & $0 \%$ & $8 \%$ & $26 \%$ & $46 \%$ & $20 \%$ \\
\hline $\begin{array}{l}\text { 6-With virtual classrooms, students can attend classes anywhere } \\
\text { and anytime. }\end{array}$ & $2 \%$ & $10 \%$ & $8 \%$ & $38 \%$ & $42 \%$ \\
\hline $\begin{array}{l}\text { 7-Virtual classes contribute to developing self-learning skills. } \\
\text { 8-Virtual classes help EFL learners to understand clearly. }\end{array}$ & $8 \%$ & $4 \%$ & $26 \%$ & $32 \%$ & $30 \%$ \\
\hline
\end{tabular}


Arab World English Journal (AWEJ) Special Issue on CALL Number 7. July 2021

Students' Perspectives toward Virtual Classes

Alkathiri, Alkulaib, Batays, Awdah\& Muwayni

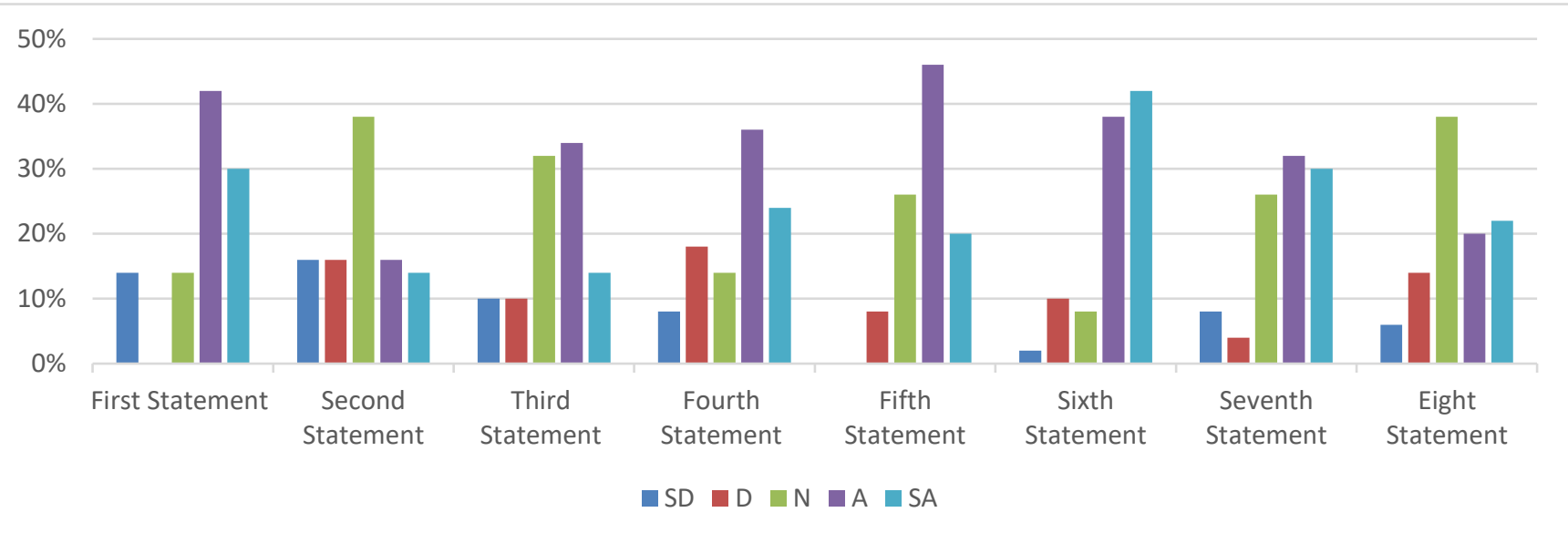

Figure 1. Students' attitudes toward virtual classrooms

The first section of the questionnaire (EFL learners' attitudes towards virtual classes) answered the first question of the study. This part was written to get students' perspectives toward virtual classes. In table and figure one, the First statement, "Virtual classes have become necessary in education" has 30\% strongly agree, $42 \%$ agree, $14 \%$ neutral and 14\% strongly disagree. In the Second statement, "Virtual classes have proved that it has a higher competence than the traditional classes", the results show $38 \%$ of the students are neutral, $14 \%$ strongly agree, $16 \%$ agree, $16 \%$ disagree and $16 \%$ strongly disagree. Most students $34 \%$ agree with the Third statement, "Virtual classes present the knowledge in an easy and effective way", while 14\% strongly agree, 32\% neutral, $10 \%$ disagree and 10\% strongly disagree. Regarding the Fourth statement, "Virtual classrooms reduce the traditional educational loads that required from students" $36 \%$ agree with it, $24 \%$ strongly agree, $14 \%$ neutral, $18 \%$ disagree and $8 \%$ strongly disagree. The Fifth statement, "Virtual classrooms develop EFL learners' technological skills" has 20\% strongly agree, 46\% agree, $26 \%$ neutral, $8 \%$ disagree. More than forty percent of the students strongly agree with the Sixth statement, "With virtual classrooms, students can attend classes anywhere and anytime", while $38 \%$ agree, $8 \%$ neutral, $10 \%$ disagree and 2\% strongly disagree. In the Seven statement, "Virtual classes contribute to developing self-learning skills" 32\% of the students agree with it, $30 \%$ strongly agree, $26 \%$ neutral, $4 \%$ disagree and $8 \%$ strongly disagree. The last statement, "Virtual classes help EFL learners' to understand clearly" shows $22 \%$ of the participants strongly agree, $20 \%$ agree, $38 \%$ neutral, $14 \%$ disagree and $6 \%$ strongly disagree.

Table and figure two show details about the participants' responses towards virtual classes and its impact on students' communication skills.

Table 2. The impact of virtual classes on students' communication skills

\begin{tabular}{|l|c|c|c|c|c|}
\hline \multicolumn{1}{|c|}{ Statement } & $\begin{array}{l}\text { Strongly } \\
\text { Disagree }\end{array}$ & Disagree & Neutral & Agree & $\begin{array}{l}\text { Strongly } \\
\text { Agree }\end{array}$ \\
\hline 1-Virtual classrooms encourage teamwork. & $12 \%$ & $28 \%$ & $22 \%$ & $30 \%$ & $8 \%$ \\
\hline $\begin{array}{l}\text { 2-Virtual classes strengthen communication skills } \\
\text { among EFL learners. }\end{array}$ & $4 \%$ & $12 \%$ & $32 \%$ & $36 \%$ & $16 \%$ \\
\hline
\end{tabular}

Arab World English Journal 
Arab World English Journal (AWEJ) Special Issue on CALL Number 7. July 2021

Students' Perspectives toward Virtual Classes

Alkathiri, Alkulaib, Batays, Awdah\& Muwayni

\begin{tabular}{|l|c|c|c|c|c|}
\hline $\begin{array}{l}\text { 3-Virtual classes allow direct communication with the } \\
\text { instructors. }\end{array}$ & $6 \%$ & $8 \%$ & $22 \%$ & $34 \%$ & $30 \%$ \\
\hline $\begin{array}{l}\text { 4-Virtual classes provide meaningful feedback } \\
\text { experiences among students. }\end{array}$ & $10 \%$ & $6 \%$ & $28 \%$ & $42 \%$ & $14 \%$ \\
\hline $\begin{array}{l}\text { 5-Virtual classrooms enhance students' participation in } \\
\text { different e-activities. }\end{array}$ & $8 \%$ & $6 \%$ & $26 \%$ & $38 \%$ & $22 \%$ \\
\hline $\begin{array}{l}\text { 6-Virtual classes provide us as students with effective } \\
\text { discussion environment. }\end{array}$ & $10 \%$ & $14 \%$ & $28 \%$ & $26 \%$ & $22 \%$ \\
\hline $\begin{array}{l}\text { 7-Virtual classes provide communicative e-tools that } \\
\text { allow us as students to share files, pictures and videos. }\end{array}$ & $4 \%$ & $0 \%$ & $16 \%$ & $56 \%$ & $24 \%$ \\
\hline $\begin{array}{l}\text { 8-Poor network connection causes problems with } \\
\text { students' interaction, participation and communication. }\end{array}$ & $8 \%$ & $0 \%$ & $12 \%$ & $14 \%$ & $66 \%$ \\
\hline
\end{tabular}

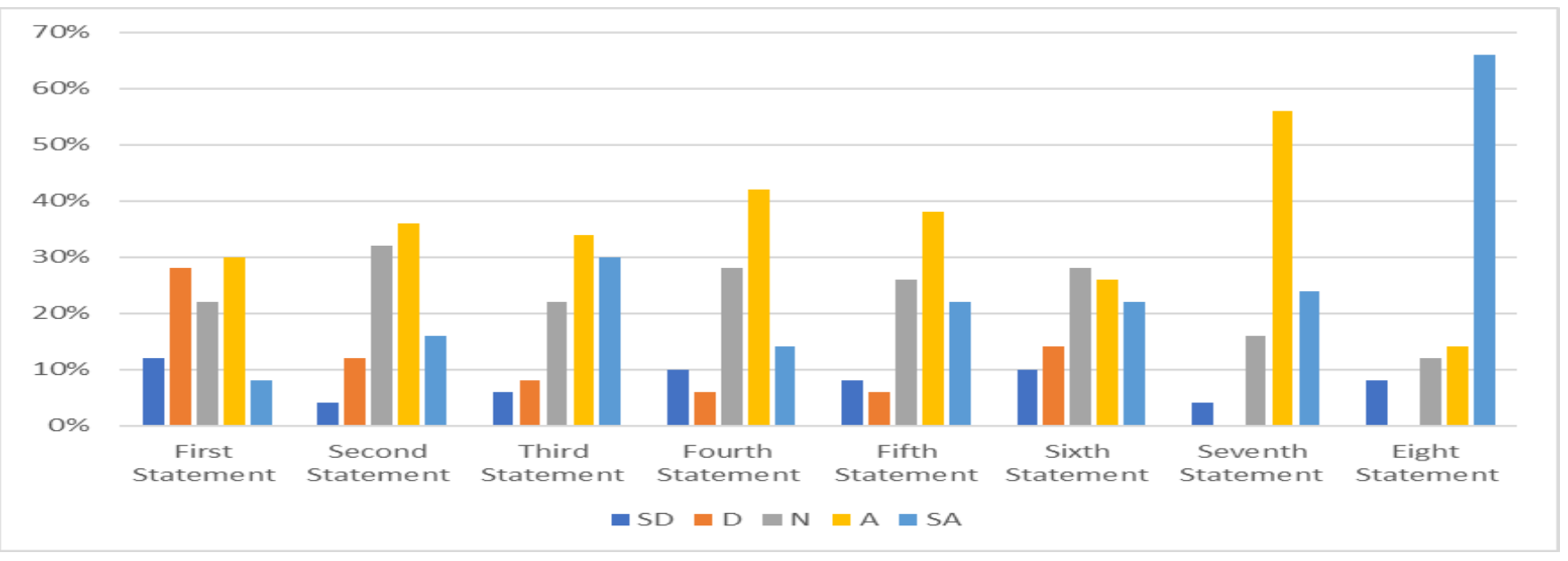

Figure 2. The impact of virtual classes on students' communication skills

According to the second section of the questionnaire (EFL students' attitudes towards the impact of virtual classes on their communication skills), it answered the second question of the study. This section was written to get participants' views towards the impact of virtual classes on their communication skills.

The results of the First statement, "Virtual classrooms encourage teamwork" has 8\% strongly agree, $30 \%$ agree, $22 \%$ neutral, $28 \%$ disagree and $12 \%$ strongly disagree. The Second statement, "Virtual classes strengthen communication skills among EFL learners" has 16\% strongly agree, $36 \%$ agree, $32 \%$ neutral, $12 \%$ disagree and $4 \%$ strongly disagree. Regarding the Third statement, "Virtual classes allow direct communication with the instructors", 30\% of students strongly agree, 34\% agree, 22\% neutral, $8 \%$ disagree and 6\% strongly disagree. Most students $42 \%$ agree with the Fourth statement, "Virtual classes provide meaningful feedback experiences among students", while 14\% strongly agree, $28 \%$ neutral, $6 \%$ disagree and $10 \%$ strongly disagree. The Fifth statement "Virtual classrooms enhance students' participation in different e-activities" has 22\% strongly agree, 38\% agree, $26 \%$ neutral, $6 \%$ disagree and $8 \%$ 
strongly disagree. In the Sixth statement, "Virtual classes provide us as students with effective discussion environment", 22\% strongly agree, 26\% agree, 28\% neutral, 14\% disagree and $10 \%$ strongly disagree. More than Fifty percent of the students agree with the Seven statement, "Virtual classes provide communicative e-tools that allow us as students to share files, pictures and videos", while $24 \%$ strongly agree, $16 \%$ neutral and only $4 \%$ strongly disagree. The last statement, "Poor network connection causes problems with students' interaction, participation and communication" shows $66 \%$ of the participants strongly agree, $14 \%$ agree, $12 \%$ neutral and $8 \%$ strongly disagree.

\section{Discussion}

The results proved that, students had positive attitudes towards virtual classes. Moreover, most participants agreed that virtual classes have become necessary in education. They believed that such classes developed their technological skills and self-learning skills. Students preferred virtual classes because they could attend classes anywhere and anytime. Furthermore, they reported that virtual classes were excellent and effective in education.

These responses explained that most of the participants agreed that virtual classes had a positive effect on their communication skills. Also, they agreed that virtual classes were an effective tool that helped them to enhance their communication skills and encourage their participation with the teachers. On the other hand, students strongly agreed that poor network connection could expose them to communicational problems. As a result, if the network connection is good, the virtual class will have an effective impact on such communication skills.

Such findings are similar to Kolarova's (2018) study, in which she said "This allows the learning experience to closely resemble real live communication". Also, the findings support Wambui (2015) study that virtual classes are a good channel for good communication. Social interaction supports creative and significant learning. Moreover, it enhances participation within virtual classes.

The results can benefit education in a positive and supportive way for our current era, where technology is widely available. The results are also important for teachers to provide enjoyable lessons for students that increase interaction between them.

\section{Conclusion}

It's apparent that communication is important in learning English as a Foreign Language (EFL) especially in virtual education. Due to the need to do more research works that focus on virtual education and learners' communication skills in Saudi Arabia, this study explored EFL students' attitudes towards virtual classes. Also, it investigated the impact of virtual classes on their communication skills. From the questionnaires' results, it was clear that many students believed that virtual classes have become necessary in education as they enhanced their communication and improved their technical and self-learning skills. Moreover, this study also highlighted the problems the students faced while attending virtual classes. So far, poor network connection was the only obstacle in EFL virtual classes. 


\section{Further Recommendations and Suggestions}

Based on the review of the findings, the current study proposes some recommendations and suggestions. First, further studies should determine the effectiveness of the virtual classes in the COVID- 19 period. Future examination can also evaluate the efficiency of virtual classes in other disciplines such as Chemistry. Second, such study should be conducted but with a different sample of students (male) to enhance their communication skills. Moreover, future studies should consider the behavioral patterns of students while using direct virtual classrooms. Finally, the same study can be applied to faculty members to collect their opinions about virtual education and its effect on communication skills.

\section{About the Authors:}

Luluh Abdullah Alkathiri got Master degree in Applied Linguistics (English Language) from Imam Muhammad Ibn Saud Islamic University, Saudi Arabia. I'm a lecturer of Applied Linguistics at the English Department of the College of Sciences and Humanities, Hotat Bani Tamim, Prince Sattam Bin AbdulAziz University, Al-Kharj, Kingdom of Saudi Arabia. Research interests focus on applied linguistics.

\section{(Alanoud Abdulaziz Alkulaib, Bashaer Saleh Batays, Khulud Mohammed Awdah and} Norah Rashed Bin Muwayni) are graduate students from the English Department at the College of Sciences and Humanities, Hotat Bani Tamim, Prince Sattam Bin AbdulAziz University, AlKharj, Kingdom of Saudi Arabia.

\section{References}

Abo Alhaj, A. (2019). The reality of using the Blackboard Learning Management System from the viewpoint of Qassim University students in studying the Introduction to Islamic Culture course. Journal of the College of Education, 35(2). p.8. Retrieved from

https://mfes.journals.ekb.eg/article_104331_6f82e53616f98677114a4276e13f3a63.pdf

Abu Hussein, K. (2016). The Impact of Technology on Education. mawdoo3 ,2016. Retrieved from https://cutt.us/QgjFT

Al-Asmari, A. M., \& Rabb Khan, M. S. (2014). E-learning in Saudi Arabia: Past, present and future. Near and Middle Eastern Journal of Research in Education, 1(1). P.3 https://doi.org/10.5339/nmejre.2014.2

Al-Attas, T. (2014). A proposal for preparing a distance education teacher in the Qur'anic scientific institutes in the Kingdom of Saudi Arabia. International Interdisciplinary Journal of Education, 3 (10), 193. p.8. Retrieved from http://www.iijoe.org/v3/IIJOE_10_10_03_2014.pdf

Al-Qahtani, M. (2019). Teachers' and Students' Perceptions of Virtual Classes and the effectiveness of Virtual Classes in Enhancing Communication Skills. Arab World English Journal (AWEJ)Special Issue: The Dynamics of EFL in Saudi Arabia, 224-240. DOI: https://dx.doi.org/10.24093/awej/efl1.16

Bolstad, R. \& Lin, M. (2009). Students' Experiences of Learning in Virtual Classrooms. New Zealand Council for Educational Research. 1-91. Retrieved from https://awej.org/images/AllIssues/Specialissues/DynamicofEFLinSaudiArabia/16.pdf Cao, Q., Griffin, T.E., \& Bai, X. (2009). The role of video and text chat in a virtual classroom. In 
J.,Yoon, \& P. Semingson, (Eds.). Educational technology and resources for synchronous learning in higher education (pp. 173-175). United States of America: IGI Global. Retrieved from https://books.google.com.sa/books?id=vGyPDwAAQBAJ

Chen, Y.W. (2002). The Merits/Defects of Distance Education for Curriculum, Teachers, and Students. Retrieved from https://mste.illinois.edu/courses/ci499sp01/students/ychen17/pages/dlearning.html

Dillenbourg, P. (1999). Virtual learning communities: Success factors and challenges. International Journal of Technology Enhanced Learning, 4(5/6), 384- 397. DOI: 10.1504/IJTEL.2012.051814

Doyle, A. D. (2020, September 17). Communication Skills for Workplace Success. Retrieved from https://www.thebalancecareers.com/communication-skills-list-2063779

Hoda, N. (2020, April 5). The Role of Virtual Classrooms During The COVID-19 Pandemic. ELearning Industry. Retrieved from

https://www.google.com/amp/s/elearningindustry.com/virtual-classrooms-role-during-covid19-pandemic/amp

Hrastinski, S. (2008). A study of asynchronous and synchronous e-learning methods discovered that each supports different purposes. Educause quarterly 31, 51-53. Retrieved from https://er.educause.edu/-/media/files/article-downloads/eqm0848.pdf

Ikrsan, Z. H. et al. (2012). Communication Skills among University Students. Procedia - Social and Behavioral Sciences, 59, 74-75. Retrieved from https://www.sciencedirect.com/science/article/pii/S1877042812036889?via\%3Dihub

Kolarova, M. (2018, September 23). Virtual Classroom Insights: Communication, Interest, and Motivation - Introduction: Part1. Retrieved from https://www.vedamo.com/knowledge/virtual-classroom-communication-interest-m otivation-part-1/

Lyon, A. (2020, May 4). What is Communication? [Video]. You Tube. Retrieved from https://www.youtube.com/watch?v=5m_u-GSvkPE

McBrien, L. (2009). Virtual Spaces: Employing a Synchronous Online Classroom to Facilitate Student Engagement in Online Learning. International Review of Research in Open Distance Learning, 10(3), 1-17. Retrieved from http://www.irrodl.org/index.php/irrodl/article/view/605/1298

McClemens, A. (2013). The Rising Importance of the Virtual Classroom. Andrew McClemens', 1-3. Retrieved from https://sites.google.com/site/andrewmcclemenshomepage/home/therising-importance-of-the-virtual-classroom

Nordquist, R. (2019, September 19). Learn the Art of Communication and See How It's Used Effectively. Retrieved from https://www.thoughtco.com/what-is-communication-1689877

Parker, M.A., \& Martin, F.(2010). Using virtual classrooms: Student perceptions of features and characteristics in an online and a blended course. MERLOT Journal of Online Learning and Teaching, 6 (1),135-147.

Preece, J. (2001). Virtual learning communities: Success factors and challenges. International Journal of Technology Enhanced Learning, 4(4/5), 383-497.

Racheva, V. (2018, May 9). What is a virtual classroom. Retrieved from https://www.vedamo.com/knowledge/what-is-virtual-classroom/ 
Taskiran, A., Gumusoglu, E., \& Aydin, B. (2018). Fostering Foreign Language learning with Twitter: Reflections from English learners. Turkish Online Journal of Distance Education, 19(1), 100. https://doi.org/10.17718/tojde.382734

The Reality of Using Classes in the Education Program From the Perspective of the Faculty at the University King Abdul Aziz in Jeddah. (2010). https://n9.cl/Ohkwv

Wambui, T. W. (2015). Communication Skills, Students Coursebook. Advances in Language and Literary Studies, $1-9$.

\section{Appendices}

\section{Appendix A: Students' Questionnaire}

Students' Perspectives towards Virtual Classes Effectiveness on EFL Learners' Communication Skills

Dear student,

This questionnaire is for research purposes only. The data which will be collected will not be used to evaluate you. This questionnaire is a part of a study that investigates Students' Perspectives of Virtual Classes Effectiveness on EFL Learners' Communication Skills. You are kindly requested to answer the following questions by ticking the appropriate box. Thank you for your collaboration.

\begin{tabular}{|c|c|c|c|c|c|c|}
\hline \multicolumn{7}{|c|}{ Section One: Students' Attitudes toward Virtual Classrooms: } \\
\hline No & Statement & $\begin{array}{l}\text { Strongly } \\
\text { Disagree }\end{array}$ & Disagree & Neutral & Agree & $\begin{array}{c}\text { Strongly } \\
\text { Agree }\end{array}$ \\
\hline 1 & Virtual classes have become necessary in education. & & & & & \\
\hline 2 & $\begin{array}{l}\text { Virtual classes have proved that it has a higher } \\
\text { competence than the traditional classes. }\end{array}$ & & & & & \\
\hline 3 & $\begin{array}{l}\text { Virtual classes present the knowledge in an easy } \\
\text { and effective way. }\end{array}$ & & & & & \\
\hline 4 & $\begin{array}{l}\text { Virtual classrooms reduce the traditional } \\
\text { educational loads that required from students. }\end{array}$ & & & & & \\
\hline 5 & $\begin{array}{l}\text { Virtual classrooms develop EFL learners' } \\
\text { technological skills. }\end{array}$ & & & & & \\
\hline 6 & $\begin{array}{l}\text { With virtual classrooms, students can attend classes } \\
\text { anywhere and anytime. }\end{array}$ & & & & & \\
\hline
\end{tabular}


Arab World English Journal (AWEJ) Special Issue on CALL Number 7. July 2021

Students' Perspectives toward Virtual Classes

Alkathiri, Alkulaib, Batays, Awdah\& Muwayni

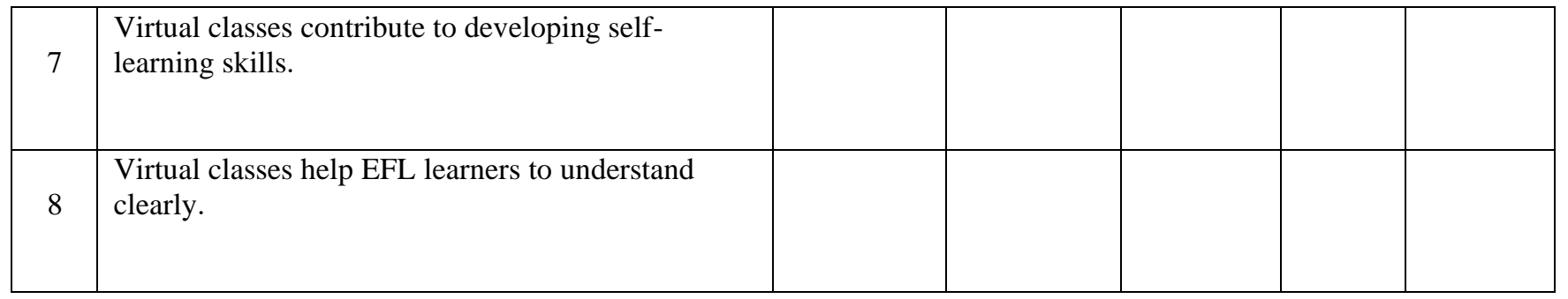

Choose the answer which describes your own opinion and tick $(\sqrt{ })$ the box next to it.

Section Two: The Impact of Virtual Classes on Students' Communication Skills

\begin{tabular}{|c|c|c|c|c|c|c|}
\hline No & Statement & $\begin{array}{l}\text { Strongly } \\
\text { Disagree }\end{array}$ & Disagree & Neutral & Agree & $\begin{array}{l}\text { Strongly } \\
\text { Agree }\end{array}$ \\
\hline 1 & Virtual classrooms encourage teamwork & & & & & \\
\hline 2 & $\begin{array}{l}\text { Virtual classes strengthen communication skills } \\
\text { among EFL learners. }\end{array}$ & & & & & \\
\hline 3 & $\begin{array}{l}\text { Virtual classes allow direct communication with } \\
\text { the instructors. }\end{array}$ & & & & & \\
\hline 4 & $\begin{array}{l}\text { Virtual classes provide meaningful feedback } \\
\text { experiences among students. }\end{array}$ & & & & & \\
\hline 5 & $\begin{array}{l}\text { Virtual classrooms enhance students' } \\
\text { participation in different e-activities. }\end{array}$ & & & & & \\
\hline 6 & $\begin{array}{l}\text { Virtual classes provide us as students with } \\
\text { effective discussion environment. }\end{array}$ & & & & & \\
\hline 7 & $\begin{array}{l}\text { Virtual classes provide communicative e-tools } \\
\text { that allow us as students to share files, pictures } \\
\text { and videos. }\end{array}$ & & & & & \\
\hline 8 & $\begin{array}{l}\text { Poor network connection causes problems with } \\
\text { students' interaction, participation and } \\
\text { communication. }\end{array}$ & & & & & \\
\hline
\end{tabular}

Thank you

Arab World English Journal 